\title{
PENERAPAN METODE DISKUSI SEBAGAI UPAYA MENINGKATKAN PRESTASI BELAJAR SISWA PADA MATA PELAJARAN IPA
}

\author{
Fatmawati \\ SD Negeri 168 Rejang Lebong \\ fatmawati168@gmail.com
}

\begin{abstract}
ABSTRAK
Penelitian ini bertujuan untuk mengetahui keaktifan siswa serta aktivitas guru, dan peningkatan prestasi belajar siswa pada mata pelajaran IPA dikelas IV di SD Negeri 168 Rejang Lebong melalui penerapan metode diskusi. Jenis penelitian yang dilakukan adalah penelitian tindakan kelas (Classroom Action Reseacrh) yang dilaksanakan dalam dua siklus, setiap siklus terdiri dari 4 tahap yaitu tahap perencanaan, tahap pelaksanaan tindakan, tahap observasi, dan tahap refleksi. Instrumen yang digunakan terdiri dari lembar observasi guru dan siswa serta lembar tes tertulis dalam bentuk essay. Data hasil belajar yang diperoleh dianalisis secara deskriptif dengan mengacu pada ketuntasan belajar klasikal. Dari analisa data menunjukkan pada siklus I diperoleh nilai rata-rata skor observasi guru sebesar 33 dengan kriteria baik, dan rata-rata skor observasi siswa sebesar 24 dengan kriteria baik, pada siklus II rata-rata skor observasi guru sebesar 35 dengan kriteria baik dan rata-rata skor observasi siswa sebesar 26 dengan kriteria baik. Hasil analisis ketuntasan belajar secara klasikal pada siklus 1 sebesar $60,60 \%$ dengan nilai rata-rata 6,78. Pada siklus II ketuntasan belajar secara klasikal meningkat menjadi $93,93 \%$ dengan nilai rata-rata meningkat menjadi 8,52 . Dengan demikian dapat disimpulkan bahwa penerapan metode diskusi meningkatkan hasil belajar siswa
\end{abstract}

Kata Kunci: Metode Diskusi, Keaktifan, Prestasi Belajar.

\begin{abstract}
This study aims to determine the activity of students and teacher activities, and increase student achievement in science subjects in class IV in 168 Rejang Lebong Public Elementary School through the application of discussion methods. The type of research conducted is Classroom Action Research conducted in two cycles, each cycle consisting of four stages, namely the planning stage, the stage of action, the observation phase, and the reflection stage. The instrument used consisted of teacher and student observation sheets and written test sheets in essay form. The learning outcome data obtained were analyzed descriptively by referring to classical learning completeness. From the data analysis showed that in the first cycle the average score of the teacher observation score was 33 with good criteria, and the average score of the observation of students was 24 with good criteria, in the second cycle the average teacher observation score was 35 with the criteria of good and average the average student observation score is 26 with good criteria. The results of classical learning completeness analysis in the first cycle amounted to $60.60 \%$ with an average value of 6.78 . In cycle II classical
\end{abstract}


learning completeness increased to $93.93 \%$ with an average value increasing to 8.52. Thus it can be concluded that the application of discussion methods improves student learning outcomes

Keywords: Discussion Method, Activity, Learning Achievement.

\section{PENDAHULUAN}

Dalam proses pembelajaran guru menjelaskan IPA lebih berorientasi produk daripada proses. Salah satu penyebabnya adalah penggunaan metode yang kurang tepat dan bervarias (Rivai, 1990). Seorang guru memegang peranan yang menentukan di dalam interaksi belajar mengajar, bagaimanapun sistem pendidikan sekolah, alat yang digunakan dan keadaan anak didik, maka pada akhirnya tergantung pada guru di dalam mengelola semua komponen yang ada. metode dan keputusan guru di dalam interaksi belajar mengajar sangat menentukan keberhasilan anak untuk mencapai pendidikan (Budianstra, 2002).

Berdasarkan hasil observasi dan wawancara dengan guru IPA, khususnya kelas IV SD Negeri 168 Rejang Lebong dengan jumlah siswa 33 orang terdiri dari 18 orang siswa laki-laki dan 15 orang siswa perempuan. Maka peneliti memperoleh keterangan bahwa pada mata pelajaran IPA nilainya masih tergolong rendah. Hal ini disebabkan oleh beberapa faktor, antara lain; karena rendahnya minat belajar siswa, cara penyampaian konsep oleh guru yang kurang sistematis dan pembelajaran yang dilakukan oleh guru lebih dominan menggunakan metode ceramah.

Peneliti mengambil mata pelajaran IPA karena pada mata pelajaran ini penanaman konsep yang baik dan benar mutlak diperlukan, hal ini disebabkan IPA merupakan ilmu pengetahuan yang berkelanjutan dari tingkat dasar ketingkat yang lebih tinggi sehingga penguasaan konsep IPA di tingkat dasar menentukan penguasaan konsep IPA di tingkat selanjutnya. Oleh karena itu, proses atau pelaksanaan pembelajaran IPA harus ditekankan pada siswa, siswalah yang aktif sementara guru hanya sebagai motivator dan fasilitator (Trianto, 2007)

Metode diskusi merupakan metode yang paling sederhana dibanding dengan metode lainnya (Roestiyah, 2002). Metode diskusi adalah suatu metode pengajaran tentang dimana guru memberi suatu persoalan(masalah) kepada murid, dan para murid diberi kesempatan secara bersama-sama untuk memecahkan masalah itu dengan teman-temannya (Budiastra, 2002)

Berdasarkan latar belakang di atas, maka dirumuskan permasalahan apakah penerapan metode diskusi dapat meningkatkan keaktifan dan prestasi belajar siswa kelas IV SD Negeri 168 Rejang Lebong. 


\section{METODE PENELITIAN}

Penelitian ini merupakan penelitian tindakan kelas (Classroom Action Research) yang merupakan suatu pencermatan terhadap kegiatan belajar berupa sebuah tindakan yang sengaja dilakukan dan terjadi dalam sebuah kelas secara bersama. Tindakan tersebut diberikan oleh guru dengan arahan dari guru yang dilakukan oleh siswa (Arikunto, 2007).

Subjek penelitian ini adalah guru dan seluruh siswa kelas IV di SDN 168 Rejang Lebong Tahun Pelajaran 20172018 dengan jumlah siswa sebanyak 33 orang yang terdiri dari 18 orang siswa laki-laki dan 15 orang siswa perempuan.

Instrumen yang digunakan penelitian ini adalah: 1) lembar observasi, lembar observasi merupakan lembar yang digunakan untuk mengamati aktifitas siswa dan guru selama proses pembelajaraan berlangsung. Observasi ini dilakukan pada saat kegiatan belajar mengajar. Lembar observasi terdiri dari lembar observasi guru dan lembar observasi siswa; 2) lembar tes hasil, tes yang dilakukan adalah berupa Post tes, LDS dan Presentasi, yang digunakan untuk mengetahui pencapaian prestasi belajar siswa terhadap materi pelajaran yang telah diberikan. Post tes dan LDS dilakukan berupa tes essay sedangkan presentasi adalah penilaian keaktifan siswa. Post tes dilaksanakan setelah proses belajar mengajar berakhir, dengan tujuan untuk mengetahui sejauh mana tingkat pencapaian siswa terhadap materi pelajaran yang telah diberikan.

Analisis data observasi yang diperoleh digunakan untuk merefleksi tindakan yang telah dilakukan. Analisis data hasil belajar diambil dari nilai akhir siswa, nilai akhir siswa terdiri dari Post tes, LDS dan Presentase, dengan persentasi sebagai berikut: Post tes 168\%, LDS 30\%, Presentasi 20\%. Data nilai akhir digunakan untuk menghitung nilai rata-rata dan nilai ketuntasan belajar berdasarkan ketentuan KTSP 2007 yaitu secara klasikal proses pembelajaran dikatakan berhasil bila siswa di kelas sebanyak $75 \%$ memperoleh nilai $\geq 7$ dan proses pembelajaran dikatakan tuntas secara individual apabila siswa memperoleh nilai $\geq 7$. Indikator keberhasilan proses pembelajaran: 1) keaktifan siswa mendapat skor 22-27; 2) keaktifan guru mendapat skor 29-36 Sedangkan ketuntasan belajar ditandai apabila prestasi belajar siswa sebagai berikut: 1) untuk individu siswa mendapat nilai $\geq 7,0$ dan 2) untuk klasikal jika $75 \%$ siswa mendapat nilai $\geq 7,0$

\section{HASIL PENELITIAN}

Dari hasil penelitian yang telah dilaksanakan dengan menerapkan metode diskusi pada pembelajaran IPA, diperoleh hasil bahwa penelitian ini dilaksanakan dengan 2 (dua) siklus sebagai berikut: 
Tabel 1

Hasil Pengamatan aktivitas guru

\begin{tabular}{ccccc}
\hline \multirow{2}{*}{ Siklus } & \multicolumn{2}{c}{ Skor } & $\begin{array}{c}\text { Rata-rata } \\
\text { Skor }\end{array}$ & Kriteria \\
\cline { 2 - 4 } I & P1 & P2 & 33 & B \\
\hline II & 34 & 32 & 33 & B \\
\hline
\end{tabular}

Aktivitas guru pada proses pembelajaran dengan metode diskusi secara keseluruhan mengalami peningkatan tiap siklus. Dapat dilihat pada siklus I ratarata skor kedua pengamat untuk aktivitas guru adalah 33 dan berada pada kriteria baik. Setalah dilakukan beberapa refleksi maka aktivitas guru meningkat pada siklus II dengan rata-rata skor menjadi 35 dan berada pada kriteria baik. Dapat dikatakan bahwa metode diskusi dapat meningkatkan aktivitas guru.

Tabel 2

Hasil Pengamatan Aktivitas Siswa

\begin{tabular}{ccccc}
\hline \multirow{2}{*}{ Siklus } & \multicolumn{2}{c}{ Skor } & \multirow{2}{*}{ Rata-rata Skor } & \multirow{2}{*}{ Kriteria } \\
\cline { 2 - 3 } & P1 & P2 & & \\
\hline I & 25 & 23 & 24 & Baik \\
\hline II & 27 & 25 & 26 & Baik \\
\hline
\end{tabular}

Aktivitas siswa pada proses pembelajaran dengan metode diskusi secara keseluruhan mengalami peningkatan tiap siklus. Dapat dilihat pada siklus I ratarata skor kedua pengamat untuk aktivitas siswa adalah 24 dan berada pada kriteria baik. Setalah dilakukan beberapa refleksi maka aktivitas siswa meningkat pada siklus II dengan rata-rata skor menjadi 26 dan berada pada kriteria baik.

Peningkatan aktivitas siswa setiap siklusnya tersebut dikarenakan guru selalu melakukan tindakan perbaikan dari siklus sebelumnya. Dapat dikatakan bahwa metode diskusi dapat meningkatkan aktivitas belajar siswa.

Data hasil tes pada siklus 1 dari 33 orang siswa kelas IV SD Negeri 168 Rejang Lebong, setelah dianalisis dengan rata-rata nilai dan ketuntasan belajar siswa secara klasikal, maka diperoleh hasil seperti pada tabel berikut ini:

Tabel 3

Rerata nilai dan ketuntasan belajar setiap siklus

\begin{tabular}{cccc}
\hline Siklus & Jumlah Siswa Tuntas & Persentase & Nilai Rerata \\
\hline I & 20 & $60,60 \%$ & 6,78 \\
\hline II & 20 & $93,93 \%$ & 8,52 \\
\hline
\end{tabular}

Dalam hal ini terlihat baahwa nilai rata-rata adalah 8,52 dan ketuntasan belajar siswa adalah 93,93\%. Ini menunjukkan bahwa proses pembelajaran pada 
siklus II sudah tuntas. Ini menunjukkan bahwa proses pembelajaran pada siklus II sudah tuntas.

\section{PEMBAHASAN}

Berdasarkan hasil panelitian yang telah dilaksanakan dalam 2 siklus pada pembelajaran IPA dengan menerapkan metode diskusi dengan subjek penelitian siswa kelas IV SD Negeri 168 Rejang Lebong dapat meningkatkan keaktifan siswa. Hal ini terlihat dari data hasil observasi guru dan siswa pada siklus I dan Siklus II yang mengalami peningkatan. Pada aktivitas guru dari rata-rata skor 33 dengan kategori baik dan meningkat menjadi 35 pada siklus II dengan kategori baik. Sedangkan untuk aktivitas siswa dari rata-rata skor 24 dengan kategori cukup pada siklus I, meningkat menjadi 26 dengan kategori baik pada siklus II. Dengan adanya peningkatan rata-rata skor terhadap aktivitas guru dan siswa dalam proses pembelajaran IPA dengan menerapkan metode diskusi sudah dilaksanakan dengan baik.

Dari hasil analisis data tes siswa, persentase ketuntasan belajar siswa secar klasikal pada proses pembelajaran IPA siklus I dan II yang dilakukan dengan menerapkan metode diskusi dapat menjadi lebih baik. Terjadi peningkatan dengan adanya diskusi dan prestasi belajar siswa meningkat. Hal ini terlihat dari peningkatan setiap aspek penilaian.

\section{SIMPULAN}

Berdasarkan hasil penelitian yang telah dilakukan maka dapat disimpulkan pelaksanaan proses pembelajaran dengan menerapkan metode diskusi dapat meningkatkan keaktifan dan prestasi belajar siswa kelas IV SD Negeri 168 Rejang Lebong.

\section{DAFTAR PUSTAKA}

Nasution, N \& Budiastra, K. (2002). Pendidikan IPA di SD. Jakarta: Universitas Terbuka.

Roestiyah. (2001). Strategi Belajar Mengajar. Jakarta: Rineka Cipta. Arikunto, S. (2007). Penelitian Tindakan Kelas. Jakarta: Bumi Aksara Sudjana, N \& Rivai, A. (1990). Media pengajaran. Bandung: Sinar Baru. Trianto. (2007). Model-Model Pembelajaran Inovatif Berorientasi Konstruktivistik. Jakarta: Prestasi Pustaka. 